\title{
Antibacterial effect of crude extract and metabolites of Phytolacca americana on pathogens responsible for periodontal inflammatory diseases and dental caries
}

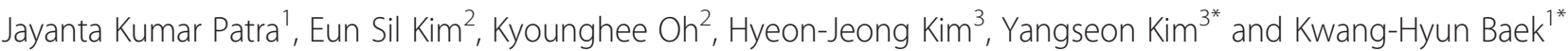

\begin{abstract}
Background: The oral cavity is the store house of different species of microorganisms that are continuously engaged in causing diseases in the mouth. The present study was conducted to evaluate the antibacterial potential of crude extracts of the aerial parts of Phytolacca americana and its natural compounds against two oral pathogens, Porphyromonas gingivalis and Streptococcus mutans, which are primarily responsible for periodontal inflammatory diseases and dental caries, as well as a nonpathogenic Escherichia coli.

Methods: Crude extract and fractions from the aerial parts of $P$. americana $(0.008-1.8 \mathrm{mg} / \mathrm{mL})$ were evaluated for their potential antibacterial activity against two oral disease causing microorganisms by micro-assays. The standard natural compounds present in $P$. americana, kaempferol, quercetin, quercetin 3-glucoside, isoqueritrin and ferulic acid, were also tested for their antibacterial activity against the pathogens at $1-8 \mu \mathrm{g} / \mathrm{mL}$.

Results: The crude extract was highly active against $P$. gingivalis (100\% growth inhibition) and moderately active against S. mutans (44\% growth inhibition) at $1.8 \mathrm{mg} / \mathrm{mL}$. The chloroform and hexane fraction controlled the growth of $P$. gingivalis with $91 \%$ and $92 \%$ growth inhibition at a concentration of $0.2 \mathrm{mg} / \mathrm{mL}$, respectively. Kaempferol exerted antibacterial activity against both the pathogens, whereas quercetin showed potent growth inhibition activity against only $S$. mutans in a concentration dependent manner.

Conclusion: The crude extract, chloroform fraction, and hexane fraction of $P$. americana possesses active natural compounds that can inhibit the growth of oral disease causing bacteria. Thus, these extracts have the potential for use in the preparation of toothpaste and other drugs related to various oral diseases.
\end{abstract}

Keywords: Kaempferol, Phytolacca americana, Porphyromonas gingivalis, Quercetin, Streptococcus mutans

\section{Background}

The mouth cavity contains many microorganisms responsible for various infections and inflammatory diseases [1]. The most common types of pathological diseases in the mouth are periodontal diseases and dental caries [2]. These diseases are caused by various plaque forming bacteria such as Streptococcus mutans, Porphyromonas gingivalis, Prevotella intermedia, Actinobacillus sp., and Fusobacterium sp.

\footnotetext{
*Correspondence: yangseon@ensoltek.co.kr; khbaek@ynu.ac.kr

${ }^{3}$ Ensoltek Co., Ltd., Techno 10-ro 51, Yuseong-gu, Daejeon 305-510, Republic of Korea

'School of Biotechnology, Yeungnam University, Gyeongsan, Gyeongbuk 712-749, Republic of Korea

Full list of author information is available at the end of the article
}

[2-4], which reside in the oral cavity. Periodontal disease is a common inflammatory disease inside the oral cavity caused by a complex biofilm of periodontopathic and resident commensal bacteria species that form an integral part of the disease along with the environment and host related factors $[5,6]$. Periodontal diseases are primarily caused by a group of anaerobic Gram-negative bacteria including P. gingivalis, P. intermedia, Actinobacillus and Fusobacterium sp. [4]. The formation of dental caries is caused by the accumulation and colonization of oral microorganisms, especially S. mutans [3], which adhere to and colonize the surface of teeth, as well as to other oral bacteria that cause 
dental plaque disease, such as Actinomyces sp., Actinobacillus sp. and Prevotella sp. [2,3].

Dental treatments in many countries are expensive and not easily accessible; therefore, people have turned to the use of medicinal plants in the form of composition of tooth paste, or simply chewing the plants directly to protect the teeth from diseases [7,8]. Different plant species of medicinal importance have successfully been included in mouthwashes and toothpastes in many developing countries $[1,9,10]$. Moreover, public research programs and dental care companies are screening medicinal plants and their extracts for their ability to control the pathogens $P$. gingivalis and $S$. mutans, which are the root cause of most oral cavity diseases.

Phytolacca americana L., which is commonly known as tropical pokeweed, belongs to the family Phytolaccaceae. P. americana L. is an herbaceous perennial plant distributed throughout most of North and South America, Africa and Asia [11,12]. Because of their antimicrobial, anti-inflammatory, anticancer and stimulatory effects, herbal preparations of this plant have been used extensively in traditional medicines in South and Central America for the treatment of many disorders including glandular swelling with heat and inflammation, syphilitic bone pain, sore throat, quinsy and diphtheria $[11,13,14]$. The use of this plant in herbal medicine is typically based on its folklore and traditional evidence. Scientific evidence on the medicinal potential and some types and nature of bioactive compounds present in this plant has been reported [12].

In the process of performing research on screening of various medicinal effects of invasive plants in the Republic of Korea funded by the National Institute of Biological Resources (NIBR, www.nibr.go.kr), the overwhelming antibacterial potential of the extracts of $P$. americana against the oral pathogens $P$. gingivalis and $S$. mutans were evaluated. In this study, therefore, various experiments investigating a range of concentrations of crude extract from $P$. americana and the individual fractions were conducted to evaluate the potential for development of new natural antibacterial medicines without affecting the normal microflora of the mouth cavity by testing the antibacterial effect of the extract on nonpathogenic Escherichia coli.

\section{Methods}

\section{Preparation of crude extract of $P$. americana}

The aerial parts (leaves and soft stem) of the wild herb $P$. americana were collected from the local area of Inchean (Sindori, Wongjin-gun, Inchon, Korea) during June 2013. Accurate identification of $P$. americana was conducted by an experienced taxonomist Jeong-Eun Han, and specimens were stored at the Natural Products Bank, Wildlife Genetic Resources Center at the NIBR (voucher number NIBRVP0000413856). The plant parts were washed twice with tap water and then dried in an oven for 3 days at $40^{\circ} \mathrm{C}$. Following drying, samples were chopped into small pieces (about $2.5 \mathrm{~cm}$ ) using a straw cutter, after which $500 \mathrm{~g}$ of dried pieces were extracted in $80 \%$ methanol using an ultrasonic apparatus. The solvent was removed under vacuum, and $17.24 \%$ is the yield of the extract. This methanolic extract was further suspended in $\mathrm{H}_{2} \mathrm{O}$, then partitioned successively with $n$-hexane, chloroform, ethanol, and $n$-butanol [15]. All crude extract and fractions were passed through a nylon membrane filter $(0.2 \mu \mathrm{m}$ pore size $)$, freeze-dried, dissolved in 5\% dimethyl sulfoxide (DMSO) and stored at $-20^{\circ} \mathrm{C}$ freezer until further use. All chemicals used in this experiment were of analytical grade and purchased from Sigma-Aldrich (St. Louis, USA).

\section{Screening of antibacterial activity of $P$. americana}

Two oral pathogenic bacteria, P. gingivalis W83 (ATCC BAA-1703 $3^{\text {max }}$ and S. mutans UA159 (ATCC $700610^{\text {max }}$ ), and one nonpathogenic bacterium, E. coli $\mathrm{DH} 5 \alpha$, used in the study were procured from the American Type Culture Collection (ATCC). P. gingivalis and S. mutans were cultured anaerobically in brain-heart infusion broth media supplemented with hemin and menadione and tryptic soy broth media, respectively $[16,17]$, and $E$. coli DH5 $\alpha$ strain was cultured in Luria-Bertuni (LB) broth media.

The antibacterial activity was evaluated by standard micro-assays using conventional sterile polystyrene microplates [18]. The assay mixture contained $50 \mu \mathrm{L}$ of inocula and $50 \mu \mathrm{L}$ of the tested extract/fraction/compounds at different concentrations $(0.2-1.8 / 0.008-0.2 \mathrm{mg} / \mathrm{mL}$ and $1-8 \mu \mathrm{g} / \mathrm{mL}$ ) respectively. Additionally, $50 \mu \mathrm{L}$ of media with $50 \mu \mathrm{L}$ of inoculum was used as a control and $50 \mu \mathrm{L}$ of media with $50 \mu \mathrm{L}$ of $5 \%$ DMSO was used as solvent control. All experiments were repeated three times and all concentrations of the extract and compounds were measured in triplicate. The natural compounds included kaempferol, quercetin, quercetin 3-glucoside, isoquercitrin and ferulic acid. The microplates were incubated at $37^{\circ} \mathrm{C}$ for $24 \mathrm{~h}$, and the growth of bacteria was determined by measuring the optical density (OD) at $630 \mathrm{~nm}$ using an ELISA microplate reader (FilterMax F5 multi-mode microplate reader, Molecular Devices, Sunnyvale, CA, USA). Minimum inhibitory concentration (MIC) of the extract was taken as the lower concentration of the extract showing no visible growth of the organism. Finally, the percentage of bacterial growth inhibition (GI) was calculated using the following formula:

$$
G I \%=\left[\left(C_{A b s}-T_{A b s}\right) / C_{A b s}\right] \times 100
$$

Where $\mathrm{C}_{\mathrm{Abs}}$ is the absorbance of the control treatment and $\mathrm{T}_{\mathrm{Abs}}$ is the absorbance of samples treated with different extracts. 


\section{Statistical analysis}

All experiments were conducted three times and the results were expressed as the means of three samples \pm the standard deviation (SD). Analysis of the variance was determined by Duncan's test using the Statistical Analysis Software (SAS) version 9.2 (SAS Inc., Cary, USA).

\section{Results}

The bactericidal effects of the crude extract and different fractions of the extracts of $P$. americana were evaluated against two oral pathogenic bacteria, $P$. gingivalis and $S$. mutans, and one nonpathogenic bacteria, E. coli DH5 $\alpha$ (Table 1$)$. At the highest concentration used $(1.8 \mathrm{mg} / \mathrm{mL})$, the crude extract was very active against $P$. gingivalis (100\% growth inhibition) and moderately active against $S$. mutans (44\% growth inhibition) (Table 1). However, the crude extract inhibited only $6 \%$ of the growth of $E$. coli $\mathrm{DH} 5 \alpha$ at the same concentration (Table 1). After further decrease in the concentration of the crude extract by three and five times ( 0.6 or $0.2 \mathrm{mg} / \mathrm{mL}$, respectively), significant suppression of the growth of $P$. gingivalis by 100 or $88 \%$, respectively, was still observed. The crude extract showed low antibacterial activity against $S$. mutans and $E$. coli DH5 $\alpha$ at the same concentrations (Table 1).

After measuring the activity of crude extract from $P$. americana against $P$. gingivalis, the crude extract was further fractioned using four different solvents. When the fractions were tested at $0.2 \mathrm{mg} / \mathrm{mL}$, the hexane and chloroform fraction significantly suppressed the growth of P. gingivalis by $92 \%$ and $91 \%$, respectively. When the concentration was further diluted by five times $(0.04 \mathrm{mg} / \mathrm{mL})$, the antibacterial effects of the hexane and chloroform fractions against $P$. gingivalis decreased significantly to $26 \%$ and $0 \%$, respectively. Evaluation of the extract of $P$. americana revealed that the hexane and chloroform fractions inhibited the growth of S. mutans by $62 \%$ and $56 \%$, respectively, at $0.2 \mathrm{mg} / \mathrm{mL}$. However, the fractions did not exert an antibiotic effect on E. coli DH5 $\alpha$ (Table 1).

The antibacterial effects of some selected natural compounds in P. americana L. such as kaempferol, quercetin, quercetin 3-glucoside, isoquercitrin and ferulic acid were also tested at different concentrations $(1-8 \mu \mathrm{g} / \mathrm{mL})$ against the two oral pathogenic and one non-pathogenic bacteria. Only kaempferol displayed higher antibacterial effects against both $P$. gingivalis and $S$. mutans and low activity against $E$. coli (Figure 1). At $8 \mu \mathrm{g} / \mathrm{mL}$, kaempferol exhibited $84 \%$ antibacterial activity against $P$. gingivalis, which was reduced to $38 \%$ when the concentration of the compound was, diluted two times (Figure 1). Further dilution resulted in loss of activity of the compound against the pathogen. Similarly, kaempferol showed $97 \%$ and $45 \%$ growth inhibition against $S$. mutans at $8 \mu \mathrm{g} / \mathrm{mL}$ and $4 \mu \mathrm{g} / \mathrm{mL}$,

Table 1 Antibacterial activity of crude extract and fractions of Phytolacca americana against the tested bacteria

\begin{tabular}{|c|c|c|c|c|}
\hline \multirow{2}{*}{$\begin{array}{l}\text { Plant } \\
\text { fractions }\end{array}$} & \multirow[t]{2}{*}{ Concentration } & P. gingivalis & S. mutans & E. coli DH5a \\
\hline & & \multicolumn{3}{|c|}{ Growth inhibition (\%) } \\
\hline \multirow[t]{4}{*}{ Crude extract } & $0.2 \mathrm{mg} / \mathrm{mL}$ & $88 \pm 19.06^{b^{* \#}}$ & $13 \pm 21.66^{y z}$ & $2 \pm 3.94$ \\
\hline & $0.6 \mathrm{mg} / \mathrm{mL}$ & $100 \pm 0.39^{a}$ & $35 \pm 25.01^{x y}$ & $3 \pm 3.20$ \\
\hline & $1.8 \mathrm{mg} / \mathrm{mL}$ & $100 \pm 0.41^{a}$ & $44 \pm 35.29^{x}$ & $6 \pm 4.45$ \\
\hline & MIC & $0.2 \mathrm{mg} / \mathrm{mL}$ & $1.8 \mathrm{mg} / \mathrm{mL}$ & - \\
\hline \multirow[t]{4}{*}{ Hexane Fr. } & $0.008 \mathrm{mg} / \mathrm{mL}$ & $0 \pm 0.00^{\mathrm{e}}$ & $2 \pm 16.46^{z}$ & $0 \pm 0.00$ \\
\hline & $0.04 \mathrm{mg} / \mathrm{mL}$ & $26 \pm 2.36^{d}$ & $0 \pm 0.00^{z}$ & $0 \pm 0.00$ \\
\hline & $0.2 \mathrm{mg} / \mathrm{mL}$ & $92 \pm 0.56^{\mathrm{ab}}$ & $62 \pm 1.49^{x}$ & $0 \pm 0.00$ \\
\hline & MIC & $0.2 \mathrm{mg} / \mathrm{mL}$ & $0.2 \mathrm{mg} / \mathrm{mL}$ & - \\
\hline \multirow[t]{4}{*}{$\mathrm{CHCl}_{3} \mathrm{Fr}$. } & $0.008 \mathrm{mg} / \mathrm{mL}$ & $0 \pm 0.00^{e}$ & $0 \pm 0.00^{z}$ & $0 \pm 0.00$ \\
\hline & $0.04 \mathrm{mg} / \mathrm{mL}$ & $0 \pm 0.00^{\mathrm{e}}$ & $0 \pm 0.00^{z}$ & $0 \pm 0.00$ \\
\hline & $0.2 \mathrm{mg} / \mathrm{mL}$ & $91 \pm 2.00^{\mathrm{ab}}$ & $56 \pm 10.52^{x}$ & $0 \pm 0.00$ \\
\hline & MIC & $0.2 \mathrm{mg} / \mathrm{mL}$ & $0.2 \mathrm{mg} / \mathrm{mL}$ & - \\
\hline \multirow[t]{3}{*}{ EtOAc Fr. } & $0.008 \mathrm{mg} / \mathrm{mL}$ & $0 \pm 0.00^{e}$ & $0 \pm 0.00^{z}$ & $7 \pm 1.90$ \\
\hline & $0.04 \mathrm{mg} / \mathrm{mL}$ & $0 \pm 0.00^{e}$ & $1 \pm 0.00^{z}$ & $2 \pm 1.38$ \\
\hline & $0.2 \mathrm{mg} / \mathrm{mL}$ & $46 \pm 5.63^{c}$ & $0 \pm 0.00^{2}$ & $0 \pm 0.00$ \\
\hline \multirow[t]{3}{*}{$\mathrm{BuOH}$ Fr. } & 0.008 mg/mL & $0 \pm 0.00^{e}$ & $0 \pm 0.00^{z}$ & $10 \pm 0.83$ \\
\hline & $0.04 \mathrm{mg} / \mathrm{mL}$ & $0 \pm 0.00^{e}$ & $0 \pm 0.00^{z}$ & $6 \pm 1.05$ \\
\hline & $0.2 \mathrm{mg} / \mathrm{mL}$ & $4 \pm 1.55^{\mathrm{e}}$ & $0 \pm 0.00^{z}$ & $0 \pm 0.00$ \\
\hline
\end{tabular}

"Data are expressed as the mean \pm SD.

\#Values in the same column with different superscript letters are significantly different $(p<0.001)$. 


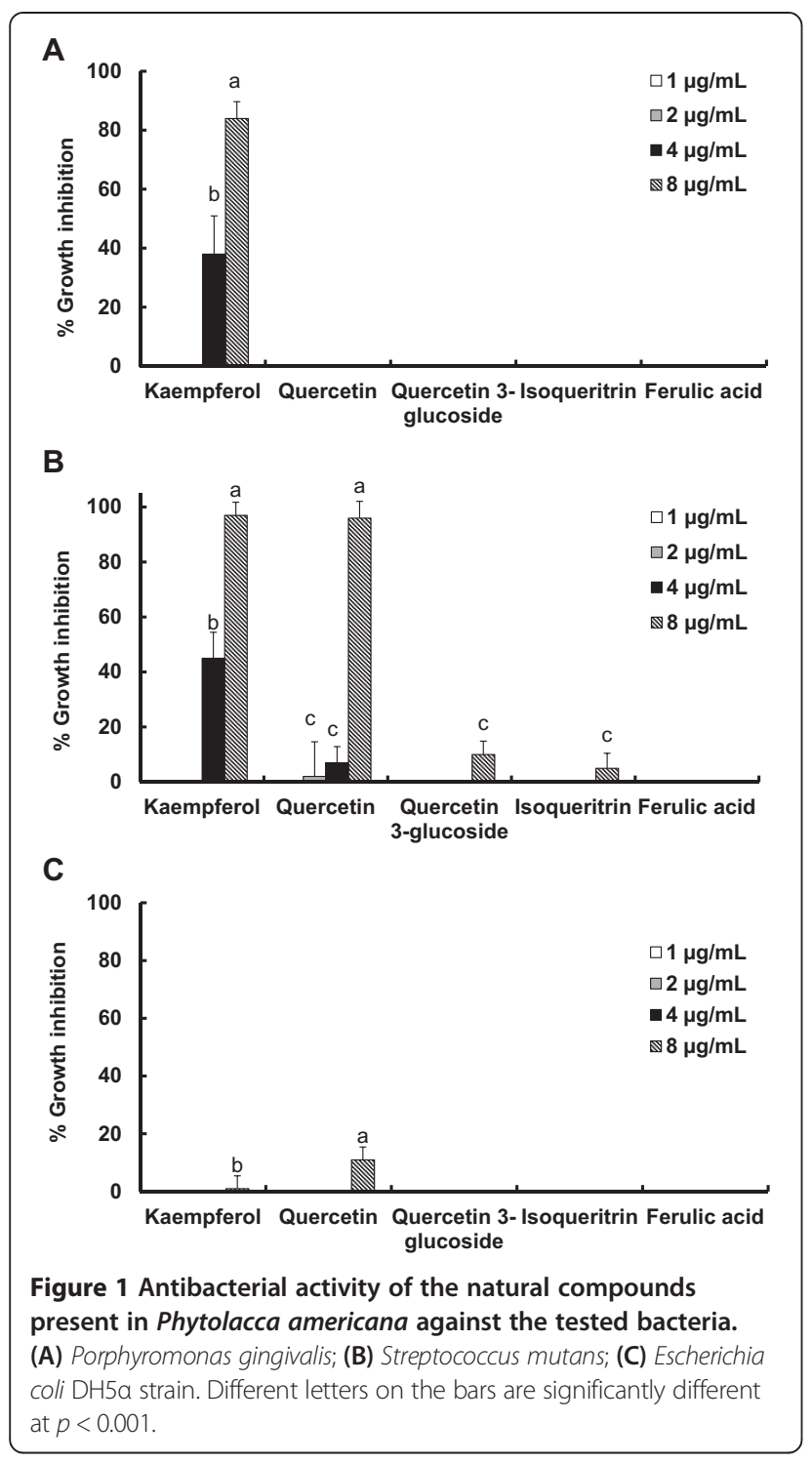

respectively (Figure 1). Quercetin exhibited 96\% growth inhibition against $S$. mutans at $8 \mu \mathrm{g} / \mathrm{mL}$, but no effect was observed against $P$. gingivalis at any of the tested concentrations.

Quercetin 3-glucoside and isoqueritrin showed very little growth inhibition activity against $S$. mutans and no activity against the other tested organisms (Figure 1). None of the natural compounds of the plant exerted significant inhibition activity against the nonpathogenic $E$. coli.

\section{Discussion}

Human pathogenic microorganisms have developed resistance to drugs owing to the extensive use of commercial synthetic antibacterial drugs in large quantity without proper medical prescriptions and tests. This condition has raised alarm in most developed and developing countries and the scientists are forced to search an alternative to these compounds, often in the form of natural medicines from resources such as plants. It is well known that in vitro evaluation of plant species with ethno-medicinal potential is the first step towards development of a new eco-friendly and effective drug against any type of infectious disease. In the present study, a similar attempt was made to search for potential bioactive compounds from P. americana for treatment of various periodontal inflammatory diseases and dental caries that are caused by pathogenic anaerobic bacteria ( $P$. gingivalis and $S$. mutans). Crude extract of $P$. americana inhibited the growth of $P$. gingivalis by $100 \%$ at 1.8 and $0.6 \mathrm{mg} / \mathrm{mL}$ (Table 1). Even diluted concentrations of $0.2 \mathrm{mg} / \mathrm{mL}$ inhibited growth by $88 \%$. Additionally, crude extract exerted moderate effects of $44 \%$ and $35 \%$ on S. mutans at 1.8 and $0.6 \mathrm{mg} / \mathrm{mL}$ (Table 1), while it had very low activity against non-pathogenic E. coli.

With an aim to identify the active fraction in which most of the antibacterial compounds are separated, the crude methanol extract was fractioned using hexane, chloroform, ethanol and butanol and then tested against the three aforementioned bacteria. Among all the fractions, hexane and chloroform fractions showed greater inhibition of the growth of $P$. gingivalis and $S$. mutans (Table 1). Significant antibacterial activity of the fraction against $P$. gingivalis might have been due to the fact that the natural bioactive compounds responsible for the antibacterial activity are mostly extracted in both the solvents and these active compounds may be able to penetrate the thick cell walls through general diffusion channels formed by the bacterial porins present therein $[2,7,19,20]$, and affect the bacterial enzymes like gingipain that are responsible for survival and virulence of $P$. gingivalis $[21,22]$ resulting in cellular lysis. However these extracts do not affect the non-pathogenic bacteria which may be due to hindrance of penetration through the outer cell wall and absence of specific enzyme in the bacteria. This mode of action of the plant extract against the specific bacteria may be due to its secondary mode of action against the bacterial enzymes instead of acting on the cell wall of the bacteria $[21,22]$.

Five most important natural compounds present in $P$. americana with possible antibacterial properties were selected and evaluated for their antibacterial activity against oral pathogens. Kaempferol showed significant antibacterial activity against both the oral pathogens in a concentration dependent manner (Figure 1), whereas only quercetin showed potent growth inhibition activity against $S$. mutans. This might have been due to easy penetration of the quercetin molecule into the Gram positive bacterial cells of $S$. mutans, resulting in disruption of the cell wall and cytoplasmic membrane [23]. Compounds such as kaempferol have previously been reported to exhibit inhibitory activity against oral 
pathogens [24,25]. Cai and $\mathrm{Wu}[26]$ demonstrated the potent growth-inhibitory activity of kaempferol against the periodontal pathogens $P$. gingivalis and $P$. intermedia. Liberio et al. [27] also reported that the active compound present in geopropolis produced by the stingless bee, Melipona fasciculate Smith and that possess antibacterial activity against oral pathogens is Quercetin. Similar effects of quercetin on oral infectious pathogens were also reported by Shu et al. [28]. The crude extract and its fractions exerted potent activity against bacterial pathogens relative to the pure natural compounds, suggesting synergistic properties of compounds that display promising antibiotic results in mixture and lose its activity when applied individually.

The antibacterial effects of the plant extract justified its ethnomedicinal uses in traditional medicine $[11,14,29,30]$. Similar investigations of the use of plants for the treatment of oral cavity infections have also been reported $[2,31]$. Additionally, the plant extract and its fractions were not very effective at inhibiting the nonpathogenic bacteria, E. coli DH5a, which indicates that, use of the plant extract as medicine or in toothpaste will only affect oral pathogenic bacteria, and not the normal flora of the mouth cavity.

\section{Conclusions}

Herbal plant extracts are a rich source of natural chemical compounds that have been utilized in various applications on the basis of their biological activities. Active compounds present in plants have shown positive results against oral pathogenic microbes and can thus facilitate management of various inflammatory diseases related to the mouth and dental caries. The present study is a preliminary attempt to investigate the antibacterial properties of aerial parts of $P$. americana against $P$. gingivalis and $S$. mutans. Based on the results of the present study, the plant fractions can be used in herbal toothpaste and medicine for the treatment of periodontal disease and dental caries. However, further research is needed to identify and characterize the active molecules responsible for their antibacterial properties and to determine its potential for use in pharmaceutical industries.

\section{Competing interests}

We declare that we do not have any competing interests.

\section{Authors' contributions \\ PJK conducted the experiment and wrote the manuscript. KE and OK collected plant samples and prepared extracts. $\mathrm{KH}$ conducted the antibacterial effects study and analyzed the data. KY and BK planned and designed the study and analysis of data. All authors participated in drafting the manuscript and have read and approved the final manuscript.}

\section{Acknowledgements}

This work was supported by the Establishment and Management of Natural Products Bank derived from Bioresources Program funded by the National Institute of Biological Resources of the Ministry of Environment.

\section{Author details}

${ }^{1}$ School of Biotechnology, Yeungnam University, Gyeongsan, Gyeongbuk 712-749, Republic of Korea. 'Wildlife Genetic Resources Center, National Institute of Biological Resources, Incheon 404-708, Republic of Korea.

${ }^{3}$ Ensoltek Co., Ltd., Techno 10-ro 51, Yuseong-gu, Daejeon 305-510, Republic of Korea.

Received: 18 June 2014 Accepted: 11 September 2014

Published: 20 September 2014

\section{References}

1. Varghese J, Tumkur VK, Ballal V, Bhat GS: Antimicrobial effect of Anacardium occidentale leaf extract against pathogens causing periodontal disease. Adv Biosci Biotechnol 2013, 4:15-18.

2. Rosas-Pinon Y, Mejia A, Diaz-Ruiz G, Aguilara MI, Sanchez-Nieto S, RiveroCruza JF: Ethnobotanical survey and antibacterial activity of plants used in the Altiplane region of Mexico for the treatment of oral cavity infections. J Ethnopharmacol 2012, 141:860-865.

3. Abdus-Salam M, Matsumoto N, Martin K, Tsuda Y, Nakao R, Hanada N, Senpuku H: Establishment of an animal model using recombinant NOD. B10. D2 mice to study initial adhesion of oral streptococci. Clin Diagn Lab Immun 2004, 11:379-386.

4. Jenkinson HF, Lamont RJ: Oral microbial communities in sickness and in health. Trends Microbiol 2005, 13:589-595.

5. Lo Bue AM, Nicoletti G, Toscano MA, Rossetti B, Cali G, Condorelli F: Porphyromonas gingivalis prevalence related to other microorganism in adult refractory periodontitis. Microbiologica 1999, 22:209-218.

6. Monetti M, Usin MM, Tabares S, Gonzalez A, Cabral HR, Sembaj A: The presence of periodonto pathogens associated with the tumour necrosis factor alpha expression in patients with different periodontal status. Acta Odontol Latinoamericana 2012, 25:82-88.

7. Shan $B, C$ ai $Y Z$, Brooks JD, Corke H: The in vitro activity of dietary spice and medicinal herb extracts. Int J Food Microbiol 2007, 117:112-119.

8. Lee DH, Seo BR, Kim HY, Gum GC, Yu HH, You HK, Kang TH, You YO: Inhibitory effect of Aralia continentalis on the cariogenic properties of Streptococcus mutans. J Ethnopharmacol 2011, 137:979-984.

9. Ohara A, Saito F, Matsuhisa T: Screening of antibacterial activities of edible plants against Streptococcus mutans. Food Sci Technol Res 2008, 14:190-193.

10. Palombo EA: Traditional plant extracts and natural products with activity against oral bacteria: potential application in the prevention and treatment of oral diseases. Evidence-Based Complement Alt Med 2011, 2011:1-15.

11. Ravikiran G, Raju AB, Venugopal Y: Phytolacca americana: A Review. Int J Res Pharma Biomed Sci 2011, 2:942-946.

12. Ding $\sqcup$, Ding $W$, Zhang $Y Q$, Luo JX: Bioguided fractionation and isolation of esculentoside P from Phytolacca americana L. Ind Crop Prod 2013, 44:534-541.

13. Gomes PB, Noronha EC, Melo CTV, Bezerra JNS, Neto MA, Lino CS, Vasconcelos SMM, Viana GSB, Sousa FCF: Central effects of isolated fractions from the root of Petiveria alliacea L. (tipi) in mice. J Ethnopharmacol 2008, 120:209-214.

14. Kubec R, Kim S, Musah RA: S-substituted cysteine derivatives and thiosulfinate formation in Petiveria alliacea -Part II. Phytochemistry 2002, 61:675-680

15. Zubair M, Rizwan K, Rasool N, Afshan N, Shahid M, Viqaruddin A: Antimicrobial potential of various extract and fractions of leaves of Solanum nigrum. Int J Phytomed 2011, 3:63-67.

16. Scgeres N, Laine ML, Sipos PM, Bosch-Tijhof CJ, Crielaard W, De Vries TJ, Everts $V$ : Periodontal ligament and gingival fibroblasts from periodontitis patients are more active in interaction with Porphyomonas gingivalis. $J$ Periodont Res 2011, 46:407-416.

17. Nassar HM, Li M, Gregory RL: Effect of honey on Streptococcus mutans growth and biofilim formation. Appl Envrion Microbiol 2012, 78:536-540.

18. Serrone PD, Nicoletti M: Antimicrobial activity of a neem cake extract in a broth model meat system. Int J Environ Res Public Health 2013, 10:3282-3295.

19. Gao Y, Van-Belkum MJ, Stiles ME: The outer membrane of Gram-negative bacteria inhibits antibacterial activity of brochocin-C. Appl Environ Microbiol 1999, 65:4329-4333. 
20. Benz R, Bauer K: Permeation of hydrophilic molecules through the outer membrane of Gram- negative bacteria. Eur J Biochem 1988, 176:1-19.

21. Sheets SM, Robles-Price AG, McKenzie RME, Casiano CA, Fletcher HM: Gingipain-dependent interactions with the host are important for survival of Porphyromonas gingivalis. Front Biosci 2012, 13:3215-3238.

22. Deris ZZ, Akter J, Sivanesan S, Roberts KD, Thompson PE, Nation RL, Li J, Velkov T: A secondary mode of action of polymyxins against Gram-negative bacteria involves the inhibition of NADH-quinone oxidoreductase activity. J Antibiot 2014, 67:147-151.

23. Kalemba D, Kunica A: Antibacterial and antifungal properties of essential oils. Curr Med Chem 2003, 10:813-829.

24. Li XC, Vander-Bijl P, Wu CD: Binaphthalenone glycosides from African chewing sticks, Diospyros lycioides. J Nat Prod 1998, 61:817-820.

25. Cowan MM: Plant products as antimicrobial agents. Clin Microbiol Rev 2003, 12:564-582.

26. Cai L, Wu CD: Compounds from Syzygium aromaticum possessing growth inhibitory activity against oral pathogens. J Nat Prod 1996, 59:987-990

27. Liberio SA, Pereira ALA, Dutra RP, Reis AS, Araujo MJAM, Mattar NS, Silva LA, Ribeiro MNS, Nascimento FRF, Guerra RNM, Monteiro-Neto V: Antimicrobial activity against oral pathogens and immunomodulatory effects and toxicity of geopropolis produced by the stingless bee Melipona fasciculata Smith. BMC Complement Alt Med 2011, 11:108.

28. Shu Y, Liu Y, Li L, Feng J, Lou B, Zhou X, Wu H: Antibacterial activity of quercetin on oral infectious pathogens. African J Microbiol Res 2011, 5:5358-5361.

29. Blainski A, Piccolo VK, Mello JCP, Oliveira RMW: Dual effects of crude extracts obtained from Petiveria alliacea L. (Phytolaccaceae) on experimental anxiety in mice. J Ethnopharmacol 2010, 128:541-544.

30. Vanichpakorn P, Ding W, Cen XX: Insecticidal activity of five Chinese medicinal plants against Plutella xylostella L. larvae. J Asia-Pac Entomol 2010, 13:169-173.

31. Rivero-Cruz BE, Esturau N, Sanchez-Nieto S, Romero I, Castillo-Juarez I, Rivero-Cruz JF: Isolation of the new anacardic acid 6-[16'Z-nonadecenyl]salicylic acid and evaluation of its antimicrobial activity against Streptococcus mutans and Porphyromonas gingivalis. Nat Prod Res 2011, 25:1282-1287.

doi:10.1186/1472-6882-14-343

Cite this article as: Patra et al.: Antibacterial effect of crude extract and metabolites of Phytolacca americana on pathogens responsible for periodontal inflammatory diseases and dental caries. BMC Complementary and Alternative Medicine 2014 14:343.

\section{Submit your next manuscript to BioMed Central and take full advantage of:}

- Convenient online submission

- Thorough peer review

- No space constraints or color figure charges

- Immediate publication on acceptance

- Inclusion in PubMed, CAS, Scopus and Google Scholar

- Research which is freely available for redistribution 